\title{
The Sustainability of Concessioning Itobe-Ajaokuta Expressway to the Private Sector
}

\author{
Apeh Ocholi Adejoh Samuel \\ Department of Civil Engineering, The Federal Polytechnic Idah, North Central, Nigeria \\ Email address: \\ engrsamapeh@gmail.com \\ To cite this article: \\ Apeh Ocholi Adejoh Samuel. The Sustainability of Concessioning Itobe-Ajaokuta Expressway to the Private Sector. International Journal of \\ Engineering Management. Vol. 4, No. 2, 2020, pp. 30-36. doi: 10.11648/j.ijem.20200402.13
}

Received: February 2, 2020; Accepted: February 20, 2020; Published: August 27, 2020

\begin{abstract}
The study focused on the Sustainability of Concessioning of Itobe-Ajaokuta Expressway to the private sector. The methodology adopted was the traffic volume count for 30 days, which enabled me to calculate the number of vehicles for each of the six different classes of vehicle plying the road daily. The study found that a total of 78,690 vehicles use the road daily. The vehicles were categorised into six (6) different groups, and tolls to be paid allocated to each of them. From the research carried out, a total of One hundred and thirty four million, four hundred and eighty thousand, six hundred naira (\#134, 480, 600 ), could be realised from toll charges annually. It was also found that the road is $5.05 \mathrm{Km}$ long and that it would cost the sum of Six hundred and eight million, four hundred and fifteen thousand, nine hundred and twenty naira (\#608,415,920), to construct the road. The key objective was to analyse whether concessioning the expressway to the private sector is sustainable, that is whether the toll charges will be able to construct and maintain the road within the concession period of thirty years. The study recommends that Kogi State government could approach the African Development Bank for loan to construct this very critical road in order to alleviate the sufferings of the Nigerian people plying the road. The study concludes that the AjaokutaItobe Expressway concession project is a viable and sustainable project, and that it will increase the welfare of the people, and directly or indirectly improve the standard of living of the people, and that rehabilitating the 5.05km of Itobe-Ajaokuta expressway will reduce environmental pollution, vehicle operating costs and travel time on the road thereby promoting economic development through improved transport services.
\end{abstract}

Keywords: Itobe-Ajaokuta Expressway, Public Private Partnerships, Sustainable Infrastructure Development, Traffic Volume Count

\section{Introduction}

The enormous resources required to fund highway infrastructure projects by the government as a result of budgetary constraints, necessitates the need for government at all tiers to seek for alternative means to fund road projects. Because of this, many countries including the developed and the developing have adopted the public-private partnership (PPP) model in order to solve their highway infrastructure problems. PPP is simply defined as a synergy between the public and private sectors in the financing and development of public infrastructures. Technically, PPP is a long term contract arrangement between a public authority and a consortium of private parties based on cooperation, with the aim of providing a mechanism for developing public service provision involving significant assets or services for a long period of time, say between 20 to 30 years. The asset or service is entrusted to the private sector consortium and a part or all of the funding comes from the private sector.

Furthermore, the road users who will be charged for using the road in form of tolls should be consulted in the planning and development process of such infrastructures. Government and private investors cannot build partnerships alone without involving the people. [3] Which means among others, the need for a holistic approach, bottom-up planning and implementation, community, and Public-Private sector financial collaboration. There is every need to involve the communities in the discussion process, especially when this involves financial obligations for which they will eventually be responsible - either through some form of taxation or user toll charges.

Toll roads are not common features in Nigerian cities. The 
few toll roads that existed along highways were suspended over a decade ago. Even then, tariff settings were not based on economic studies. Nigerians are not used to the concept of tolls on urban roads. The development and provision of road infrastructure is capital intensive. The Federal Government of Nigeria will require US\$100bn of investment in infrastructure development over the next ten (10) years coupled with the Nigerian population growth and demands for infrastructural facilities out of which US\$14bn will be for road maintenance and development in Nigeria. [14]

\subsection{Background of Study Area}

The study area is situated along Ajaokuta Interchange Itobe Niger Bridge expressway, in Kogi state, North Central Nigeria. This particular road connects Northern Nigeria with the South Eastern Nigeria, South South, and even part of South western Nigeria.

It lies between longitude $6^{\circ} 40 \mathrm{E}$ and $6^{\circ} 48 \mathrm{E}$ and Latitude $7^{\circ} 22 \mathrm{~N}$ and $7^{\circ} 30 \mathrm{~N}$ (Figure 1). The study area falls within the extreme Eastern part of the South Western basement complex of Nigeria. The basement complex consists of Ebumean granite and metamorphic rocks into which are folded Upper Proterozoic supra-crystal low grade metasediments and metavolcanic rocks forming N-S elongated belts pan-African granitoids mark the last major event and they have intrusive and/or tectonic relationships with the earlier units. Field geologic and petrographic studies of the marble and the associated rocks of Itobe area in central Nigeria show that the structures observed in the rocks include foliation, minor folds, joints and fractures. (8), The road is a dual carriageway, with two lanes on each of the carriageway, and a length of about $5.05 \mathrm{~km}$. The asphalt surface is in very bad condition and muddy. Torrents of rainfall, has created circular depressions of varying diameters along the road. It is a huge frustration to Nigerians of all classes plying that road, a key link between Abuja, the Federal capital territory and Southern Nigeria.
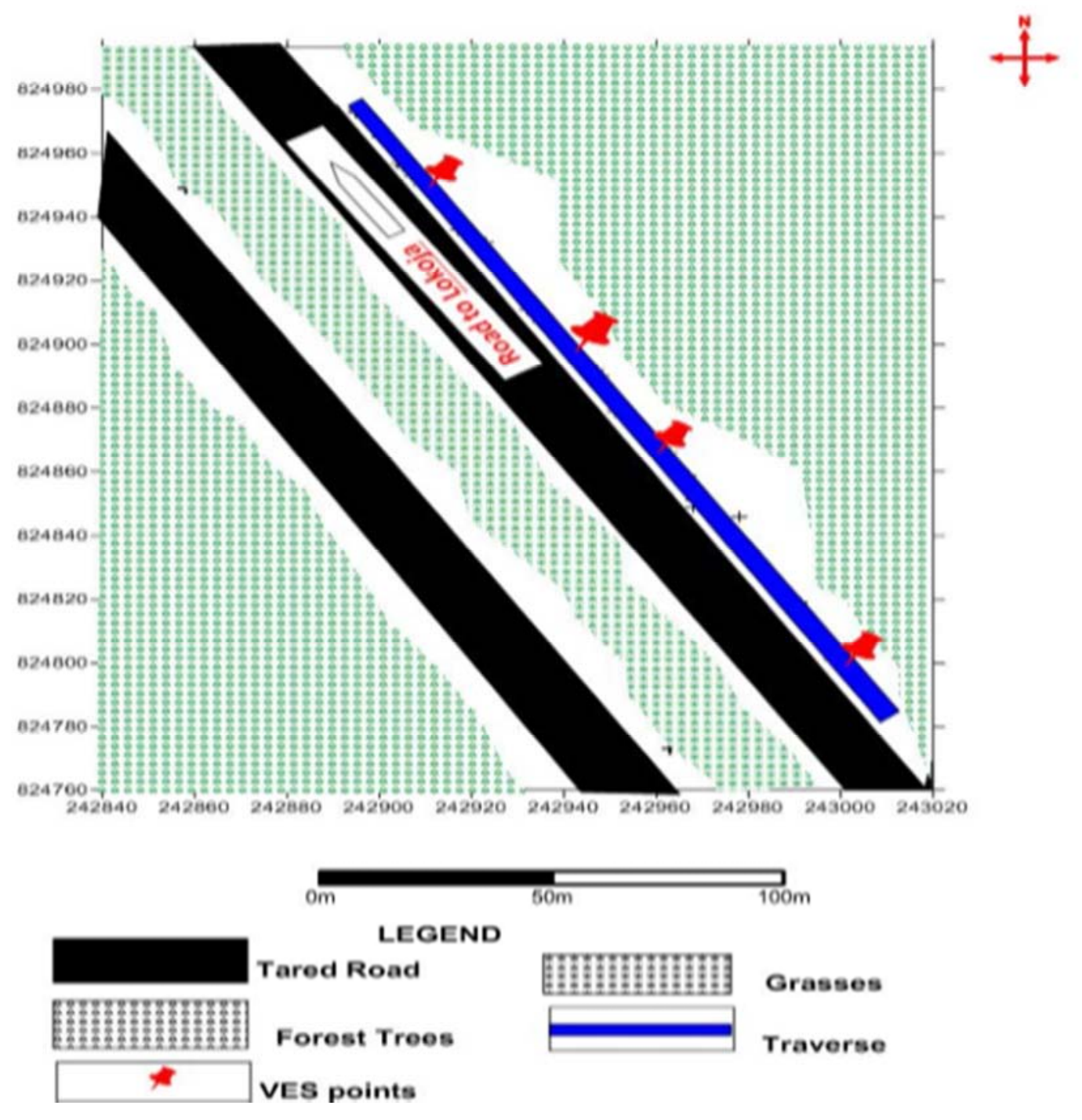

Figure 1. Basement map of the study area.

The road is a trunk ' $A$ ' road (owned by the Federal Government of Nigeria), but because of the socio-economic importance of the road to Kogi state. The government of Kogi state in collaboration with the private sector is willing 
to rehabilitate the road to reduce the sufferings of the good people of the state.

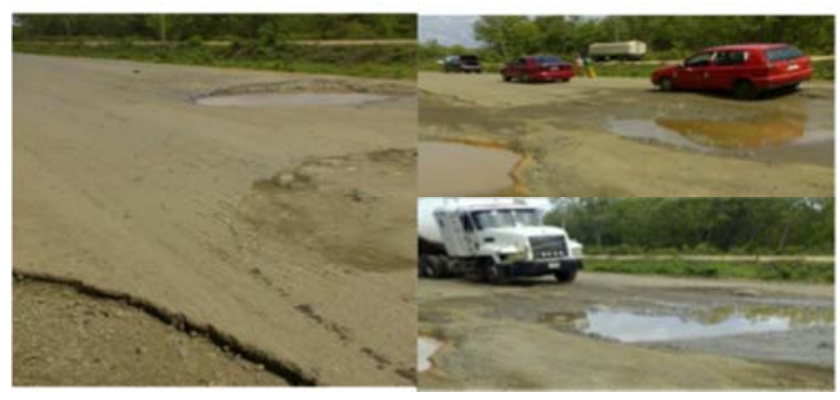

Figure 2. Failed Portion of Itobe-Ajaokuta Expressway.

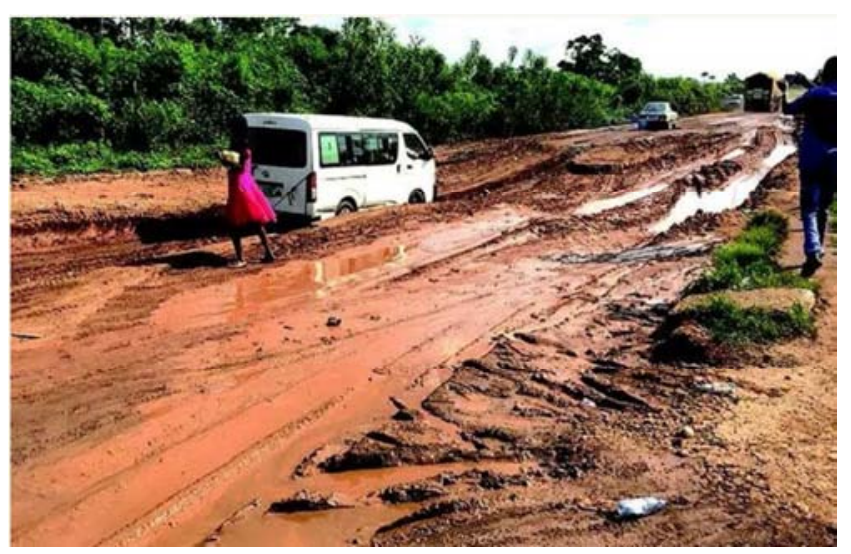

Figure 3. Failed portion of Itobe-Ajaokuta Expressway.

\subsection{Aim of Study}

The main aim of this research is the need to reduce the global infrastructure deficit and rescue infrastructure sustainability crises, especially in the developing countries such as Nigeria where there is paucity of fund and dwindling managerial capacity of the public sector, rendering sole dependency on public funding and conventional procurement methods inadequate.

\subsection{Objectives of Study}

The broader objective of the study is to provide improved and sustainable access to economic opportunities and social services, and to enhance the capacity of relevant government institutions to deliver infrastructural development targets and subsequently, to enhance the socio-economic development of the State. Moreover, at completion, the road is expected to serve as a link between the Federal capital territory and Southern Nigeria. It thus has enormous potentials for increasing economic activities capable of enhancing income generating capacity, and revenue and employment generation for the region.

\subsection{Statement of Problem}

In the past the government has been the sole financier of infrastructure finance and has often taken responsibility for implementation, operations and maintenance as well. There is a gradual recognition that this may not be the best way to execute or finance these projects. This recognition is based on considerations such as cost efficiency, equity considerations, and fiscal prudence. It is against the strength of these arguments that the author has accepted the fact that for a sustainable transport infrastructure development in Nigeria, the public sector must collaborate with the private sector, in view of the dwindling budgetary provisions for road development in Nigeria.

\subsection{Project Rationale and Need}

The project will support economic and social development programmes of Kogi State and Nigeria as a whole through efficient and cost-effective movement of passengers and freight, especially agricultural produce. Rehabilitating the $5.05 \mathrm{~km}$ of Itobe-Ajaokuta expressway will reduce environmental pollution, vehicle operating costs and travel time on the road thereby promoting economic development through improved transport services. The concessioning period is thirty (30) years.

\section{Literature Review}

\subsection{Nigerian Road Transport Infrastructure}

Road is an important infrastructure in a nation or community of people. It greatly affects the economy of any nation [13]. Roads must be properly designed and constructed. After construction, they need to be maintained to ensure that the objective of safety, strength and durability are met. Failures on Nigerian roads, major and minor, had become a normal thing to the Nigerian populace. Road failure leads to accidents on Nigerian roads [1]. Many newly constructed and rehabilitated roads in the country do not last long enough before failure. Roads are built to provide safe passage of vehicles and must be properly designed and constructed. After construction, there arise need for appropriate maintenance for the road to attain its design life and to ensure that the objectives of safety, strength and durability are met. The rate at which roads deteriorates in service ranges from the quality of materials used, workmanship standard and to the quality of design and supervision during the road construction [7].

Nigeria has about $200,000 \mathrm{~km}$ of roads spread all over the country, these roads are made up of over $32,000 \mathrm{~km}$ of federal roads spread over the thirty-six states and the federal capital, over $30,000 \mathrm{~km}$ of state roads and over $130,000 \mathrm{~km}$ of local government roads". Within the states, the local government roads are further classified into urban and rural roads. According to ownership, Nigerian roads are classified into federal, state, and local government roads, [14].

Federal roads are divided into federal trunk ' $A$ ' roads and the federal trunk ' $F$ ' roads. The federal trunk ' $A$ ' roads are those under the federal government ownership and they are developed and maintained by the federal government while the federal trunk ' $F$ ' roads are those that were formerly under the state ownership but were taken over by the federal 
government with a view to upgrading them to federal highway standards. State roads are classified as the state trunk ' $\mathrm{B}$ ' roads and are under the ownership and management of the various state governments. Local roads classified as the local government trunk ' $\mathrm{C}$ ' roads and are the roads under the ownership and management of the local governments in the country. These roads are divided into the urban, rural and village access roads [14].

\subsection{The Structure of Nigeria Road Networks}

The distribution of Nigeria road network is $17 \%, 16 \%$ and $67 \%$ (figure 1) for Federal, State and Local governments respectively. Although the Federal roads account for only $17 \%$ of the total network size, they carry the heaviest volume of traffic estimated at well over $70 \%$ (figure 2) and $90 \%$ of socio-economic activities in the country. The Federal highways are the main trunk routes linking all the thirty six states and the Federal Capital Territory, Abuja as well as leading to the main sea ports of the nation $[10,15]$.

Nigeria's transport infrastructure stock is inadequate for the size of the economy and constitutes a major cost and constraint for both large and small businesses. It lags behind its peers in terms of scale (i.e., road and rail density) and quality [17]. Nigeria can only boast of $22 \mathrm{~km}$ of roads per every $100,000 \mathrm{~km}^{2}$; compared with India, South Africa, and Kenya which have $158 \mathrm{~km}, 62 \mathrm{~km}$, and $28 \mathrm{~km}$ respectively of roads per $100,000 \mathrm{~km}^{2}$. For the rail subsector, Nigeria until recently had only $4 \mathrm{~km}$ of rail per every 1,000 square $\mathrm{km}$ compared to India, South Africa, and Kenya, which have $23 \mathrm{~km}, 17 \mathrm{~km}$, and $6 \mathrm{~km}$ respectively of rails per $1,000 \mathrm{~km}^{2}$. With more than $90 \%$ of freight and passengers carried by the roads, Nigeria's road network is highly overused, leading to rapid deterioration. The railways, which catered for about $60 \%$, freight movement at independence, now account for less than $1 \%$ land transportation in the country. The country's transport problem is exacerbated by the near total lack of maintenance of the road network at all tiers of Government (Federal, State, and Local Government) [16].

\section{Ownership Structure}

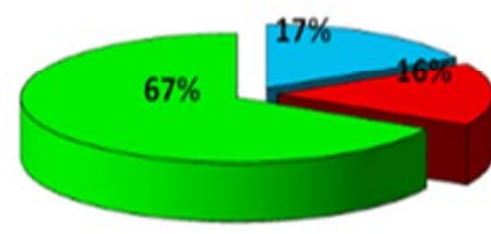

口Federal Roads

aState Roads

口Local Govt. Roads

Figure 4. Ownership structure of Nigeria Roads Network (FERMA, 2018) [7].

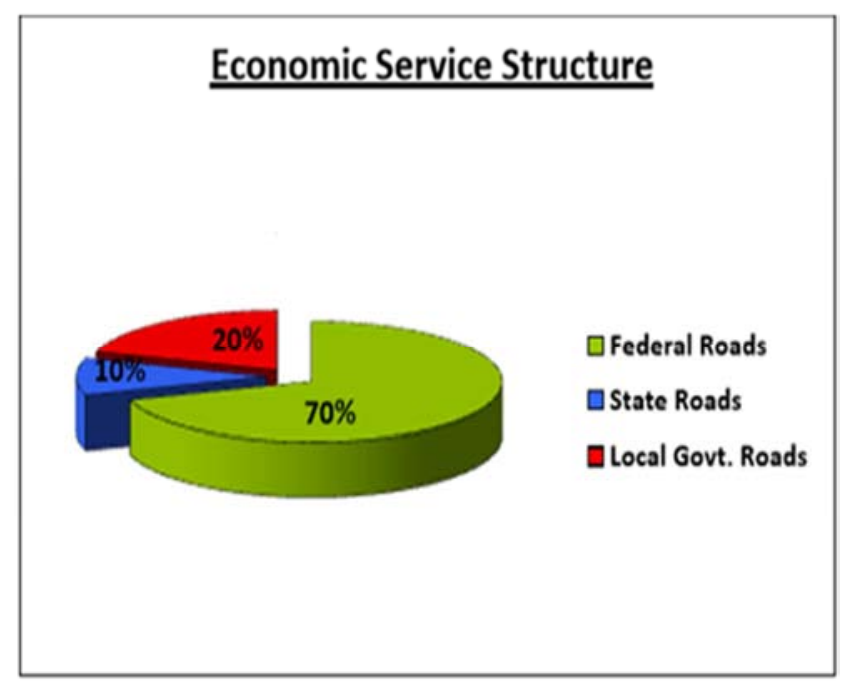

Figure 5. Economic service structure of Nigeria Roads Network (FERMA, 2018) [7].

\subsection{Public Private Partnership Prospects in Achieving Sustainable Highways in Nigeria}

Public Private Partnership (PPP) is defined as "a contractual arrangement between a public sector agency and private sector concern, whereby resources and risks are shared for the purpose of delivering a public service, or for developing public infrastructure." $[9,12]$. In highway PPP, the private sector consortium designs, builds, finances, and operates the highways for government to pay for its use (Availability Payment) or User pay (Toll). The User pay (Toll) is the method being proposed for the Ajaokuta-Itobe expressway.

The development and provision of road infrastructure in Nigeria has primarily been through the traditional forms of procurement strategies by the federal, state, and local governments through budgetary allocations and donorfinanced loans and grants, this leaves the Nigerian road infrastructure in a precarious situation [11]. But in recent time, with the demand for the development of more road infrastructure due to population explosion and urban-rural migration, coupled with financial crisis as a result of global economic meltdown, the federal government of Nigeria is now seeking collaboration with the private sectors in the development of road infrastructure facilities through publicprivate partnership (PPP). [9].

It was estimated that annual infrastructure investment of between 6 billion and 9 billion US Dollars is required to resuscitate road infrastructure in Nigeria, which cannot be provided by the government alone except through partnering with the private sector [2]. Road projects attract a meagre 18$24 \%$ cash backing resulting in a huge budget deficit [4].

\section{Materials and Method}

The methodology adopted was the traffic volume count for 30 days, which enabled me to calculate the number of vehicles for each of the six different classes of vehicle plying 
the road daily. To determine the traffic volume, field assistants were strategically stationed in various locations at different hours of the day, for 30 days, to take count of the volume of traffic. Based on this, a traffic volume of 78,690 vehicles per day was estimated. The route serves both intracity and intercity traffic. The vehicles were categorised into six (6) different groups, based on tolls to be paid. A total of One hundred and thirty four million, four hundred and eighty thousand, six hundred naira (\#134, 480, 600), could be realised from toll charges annually. It was also found that the road is $5.05 \mathrm{Km}$ long and that it would cost the sum of Six hundred and eight million, four hundred and fifteen thousand, nine hundred and twenty naira $(\# 608,415,920)$, to construct the road. The project will be able to sustain itself within the concession period. The study assumes that the number of vehicles will increase annually; motorcycles by $10 \%$, cars by $5 \%$, Buses by $3 \%$ and trucks by $2 \%$. This information is based on the observed changes in the flow of traffic over time, and projected economic activities along this corridor. At the moment, two thriving manufacturing companies, West African Ceramics Limited, and Royal Engineered Stones Limited, with employees running into thousands are operating on this corridor, and many other companies are springing up, making this particular corridor the future industrial hub of kogi state.

Table 1. Traffic Count on Ajaokuta-Itobe Expressway.

\begin{tabular}{|c|c|c|c|c|c|c|}
\hline & Class A & Class I & Class IIIA & Class III & Class IV & Class II \\
\hline Days & Motorcycles & $\begin{array}{l}\text { Saloon cars \& } \\
\text { tricycles }\end{array}$ & $\begin{array}{l}\text { Commercial } \\
\text { buses }\end{array}$ & $\begin{array}{l}\text { Light trucks \& 2- } \\
\text { axle trucks }\end{array}$ & $\begin{array}{l}\text { Heavy trucks \& } 2 \text { or more } \\
\text { heavy (loaded) axles }\end{array}$ & $\begin{array}{l}\text { Mini buses \& } \\
\text { pick up vehicles }\end{array}$ \\
\hline 1 & 581 & 502 & 271 & 164 & 306 & 97 \\
\hline 2 & 573 & 486 & 283 & 173 & 294 & 76 \\
\hline 3 & 563 & 521 & 274 & 180 & 323 & 86 \\
\hline 4 & 490 & 482 & 271 & 178 & 326 & 69 \\
\hline 5 & 504 & 503 & 290 & 192 & 286 & 71 \\
\hline 6 & 597 & 490 & 272 & 162 & 295 & 91 \\
\hline 7 & 543 & 589 & 264 & 173 & 331 & 81 \\
\hline 8 & 563 & 671 & 256 & 102 & 332 & 87 \\
\hline 9 & 532 & 587 & 275 & 124 & 341 & 48 \\
\hline 10 & 521 & 604 & 281 & 141 & 407 & 74 \\
\hline 11 & 587 & 573 & 246 & 153 & 421 & 65 \\
\hline 12 & 561 & 625 & 271 & 206 & 381 & 124 \\
\hline 13 & 671 & 658 & 268 & 123 & 330 & 118 \\
\hline 14 & 654 & 751 & 289 & 156 & 386 & 132 \\
\hline 15 & 598 & 608 & 301 & 202 & 401 & 125 \\
\hline 16 & 789 & 684 & 397 & 173 & 380 & 142 \\
\hline 17 & 765 & 690 & 401 & 164 & 390 & 103 \\
\hline 18 & 678 & 586 & 254 & 268 & 403 & 101 \\
\hline 19 & 673 & 581 & 272 & 294 & 379 & 87 \\
\hline 20 & 596 & 576 & 198 & 306 & 463 & 95 \\
\hline 21 & 1011 & 710 & 259 & 209 & 483 & 152 \\
\hline 22 & 635 & 731 & 282 & 151 & 440 & 64 \\
\hline 23 & 1015 & 2006 & 795 & 655 & 857 & 125 \\
\hline 24 & 953 & 2098 & 850 & 305 & 971 & 166 \\
\hline 25 & 841 & 4065 & 2088 & 264 & 779 & 430 \\
\hline 26 & 1016 & 3041 & 2043 & 103 & 684 & 313 \\
\hline 27 & 203 & 602 & 180 & 147 & 218 & 120 \\
\hline 28 & 190 & 569 & 165 & 136 & 102 & 76 \\
\hline 29 & 789 & 561 & 248 & 147 & 441 & 67 \\
\hline Total & 18,692 & 26,150 & 12,544 & 5769 & 12,150 & 3,385 \\
\hline
\end{tabular}

Total traffic volume per day is $18,692+26,150+12,544+5769+12,150+3,385=78,690$ vehicles.

Table 2. Classes of vehicle and the proposed toll tariff.

\begin{tabular}{lll}
\hline Vehicle class & Description & Toll (\#) \\
\hline Class A & Motorcycles & $50 \times 18,692=904,600$ \\
Class I & Saloon cars and tricycles & $100 \times 26,150=2,615,000$ \\
Class II & Mini buses, pick-up trucks & $150 \times 3,385=507,750$ \\
Class IIIA & Commercial buses & $200 \times 12,544=2,508,800$ \\
Class III & Light trucks and 2-axle buses & $250 \times 5,769=1,442,250$ \\
Class IV & Heavy trucks and 2 or more axle trucks & $300 \times 12,150=3,645,000$ \\
& & Total=\#11,623,400/month \\
\hline
\end{tabular}


Table 3. Projected Revenue.

\begin{tabular}{ll}
\hline Total amount realisable from tolls & Period \\
\hline$\# 11,623,400$ & 1 month \\
$\# 138,480,600$ & I year \\
$\# 2,077,209,000$ & 15 years \\
$\# 2,769,612,000$ & 20 years \\
$\# 4,154,418,000$ & 30 years \\
\hline
\end{tabular}

Table 4. Rough estimate for the repair of $1 \mathrm{Km}$ repair of road in Nigeria.

\begin{tabular}{|c|c|c|c|c|c|}
\hline $\mathbf{S} / \mathbf{N}$ & Description & Unit & Quantity & Rate & Amount \\
\hline \multirow[t]{3}{*}{1} & Site clearance $1 \mathrm{Km}=1,000 \mathrm{~m}$ & HA & 1.6 & 550,000 & 880,000 \\
\hline & $1000 \times 16 \mathrm{~m}($ width $)=16,000 \mathrm{~m}$ & & & & \\
\hline & $16,000 / 10,000=1.6 \mathrm{HA}$ & & & & \\
\hline \multirow[t]{4}{*}{2} & Earthworks - Cut to spoil & M & 14,000 & 950 & $13,300,000$ \\
\hline & Depth $=1 \mathrm{~m}$ & & & & \\
\hline & Width $=14 \mathrm{~m}$ & & & & \\
\hline & Length $=1 \mathrm{Km}=1,000 \mathrm{~m} .=1 \times 14 \times 1000=14000$ & & & & \\
\hline \multirow[t]{4}{*}{3} & Earthworks - Borrow to fill & M & 14,000 & 1150 & $16,100,000$ \\
\hline & Depth $-1 \mathrm{~m}$ & & & & \\
\hline & Width $-14 m$ & & & & \\
\hline & Length $-1000 \mathrm{~m}=1 \mathrm{Km}=1 \times 14 \times 1000=14000$ & & & & \\
\hline \multirow[t]{4}{*}{4} & Sub base Depth $=0.20$ & M & 2,560 & 3,200 & $8,192,000$ \\
\hline & Width $=12.80$ & & & & \\
\hline & Length $=1000$ & & & & \\
\hline & $1000 \times 0.2 \times 12.80=2,560$ & & & & \\
\hline 5 & Stone-base $-1000 \times 0.2 \times 12.80$ & $\mathrm{M}^{2}$ & 2,560 & 6,940 & $17,766,400$ \\
\hline 6 & Prime coat- $7.3 \times 1000=7,300$ & $\mathrm{M}^{2}$ & 7,300 & 550 & $4,015,000$ \\
\hline 7 & Asphaltic Binder Course & $\mathrm{M}^{2}$ & 7,300 & 4500 & $32,850,000$ \\
\hline 8 & Tack coat & $\mathrm{M}^{2}$ & 7,300 & 250 & $1,825,000$ \\
\hline \multirow[t]{2}{*}{9} & Asphaltic Concrete Wearing Course & $\mathrm{M}^{2}$ & 7,300 & 3500 & $25,550,000$ \\
\hline & & & & & $120,478.400$ \\
\hline
\end{tabular}

It would cost $\# 120,478,400$ to repair one KM of road in Nigeria. So for the Ajaokuta-Itobe road that is $5.05 \mathrm{~km}$, the total cost of rehabilitating the road is $\# 120,478,400 \times 5.05=\# 608,415,920$.

\section{Interpretation and Discussion of Results}

The vehicles were categorised into six (6) different groups. Based on tolls to be paid, a total of One hundred and thirty four million, four hundred and eighty thousand, six hundred naira (\#134, 480, 600), could be realised from toll charges annually. The total length of the road is $5.05 \mathrm{Km}$ and it would cost the sum of Six hundred and eight million, four hundred and fifteen thousand, nine hundred and twenty naira (\#608,415,920), to construct the road. The study assumes that the number of vehicles will increase annually; motorcycles by $10 \%$, cars by $5 \%$, Buses by $3 \%$ and trucks by $2 \%$. This information is based on the observed changes in the flow of traffic over time, and projected economic activities along the route. At the moment, two thriving manufacturing companies, West Africa Ceramics Limited, and Royal Engineered Stones Limited, with employees running into thousands are operating on this corridor, and more companies are springing up, making this particular corridor the industrial hub of kogi state, Nigeria.

\section{Recommendations and Conclusions}

\subsection{Recommendations}

From experience, stakeholder consultation and comprehensive studies for infrastructure provision is not the norm in Nigeria, and this is the genesis of many white elephant projects in the country. It is therefore recommended that such studies should be carried out before embarking on any infrastructure project for which users will be expected to pay user charges. Application of similar studies in other Nigerian cities in the recommended manner will be of great benefit in improving infrastructure provision and economic development in the country. Transparency and stakeholder analysis and involvement will be helpful in attracting private investors [18]. Toll road projects are fraught with a lot of risks and adequate care must be taken through comprehensive socio-economic studies to minimize such. Public Private Partnerships can bring added value to the development of transport infrastructure in Nigeria, but a sound legal and regulatory framework and complete 
transparency particularly with regards to financial accountability are essential elements. Also important is the presence of strong structure at the level of central administration to steer and guide policy implementation. PPPs indeed often falter because of hastily prepared tender documents and contracts and the negotiations taking place between unequally qualified and experienced professionals, mainly to the disadvantage of the representative from the public sector.

Alternatively, Kogi state government could approach the African Development Bank (AfDB) for funds, for this project, as this will reduce the cost of construction, when compared with the local commercial banks whose interest rates are so high. But because maintenance of road infrastructure is a huge challenge to the public sector. Partnering the private sector is what the author of this research recommends.

\subsection{Conclusions}

With the positive outcome of the feasibility studies, the provision of adequate sustainable infrastructure cannot be left in the hands of government alone. In Nigeria and other developing countries, sustainable access to road infrastructure and other socio-economic services and products can be accomplished through public-private partnerships, where the government delivers the minimum standard of services and products, while the private sector brings skills and core competencies. Donors and the business class bring funding and other resources. Such collaboration will be quite productive.

In a bid to bring about sustainable development in most countries, it is no longer sustainable for the public sector to finance the road infrastructure alone. Efficient and effective production and distribution of public goods and services should be part of the social contribution of the private sector to sustainable economic development. Private sector led economic growth and development, is generally more efficient (both productive and allocative efficiencies) and effective. The private sector is more dynamic, resilient, creative, innovative and vibrant that the public sector. But because private sector is more profit-oriented, the provision of infrastructures cannot be left alone in the hand of the private sector. Since there will still be some elements of market imperfection, that is why it is important to adopt public private partnership in the development of Ajaokuta-Itobe expressway, given the positive outcome of the feasibility studies.

\section{References}

[1] Adams, J. O. and Adetoro A. E.(2017) Analysis of Road Pavement Failure caused by soil properties along Ado Ekiti Akure Road. Nigeria International Journal of Novel Research in Engineering and Applied Sciences (IJNREAS) 1 (1) 2.

[2] Afolayan, O. D, and Abidoye, A. O. (2017). Causes of failure on Nigerian Roads: A review. Journal of Advancement in Engineering and Technology.

[3] Apeh, O. A. S. (2018). Introduction of fuel tax for road maintenance in Nigeria: A paper presented at the 4th annual
National Conference of the school of General Studies, Kogi State Polytechnic Lokoja on the 29th - 2nd July, 2018.

[4] Apeh, O. A. S, and Apeh, S. (2018). Maintenance culture and Infrastructure Development: Road Transport Infrastructure, a paper presented at the 4th annual National Conference of the school of General Studies, Kogi State Polytechnic Lokoja on the 29th - 2nd July, 2018.

[5] Babatunde, S. O, Perera, S, Zhou, L, Udeaja, C. (2017). Barriers to public private partnership projects in developing countries. Eng. Constr. Archit. Manag. 22 (6), 669-691.

[6] Ehonwa, J. (2013) "Important Facts about the Lekki-Epe Expressway"; Connect Nigeria, https://www.connectnigeria.com/articles/2013/04/importantfacts-about-the-lekki-epe-expressway/.

[7] Federal Roads Maintenance Agency, FERMA (2018). "Current state of Nigerian Road Networks.

[8] Imasuen O. I., Olatunji J. A. and Onyeobi T. U. S. (2017); Geological observations of basement rocks, around Ganaja, Kogi State, Nigeria, International Research Journal of Geology and Mining (IRJGM) (2276-6618) Vol. 3 (2) pp. 5766. Journal of Engineering Research \& Technology (IJERT) Vol. 1 Issue 8.

[9] Infrastructure Concession Regulatory Commission (2017). Report on Public private sector participation in Nigeria, July, 2017.

[10] MC Consulting (2017)."Classification of Nigerian Roads: State of Infrastructure Report on Nigerian Highways, July, 2017, pp 5-6.

[11] Maduegbuna, N. E (2012) 'On Lekki toll road concession project'. (Businessday, Thursday, January 19) http://businessdayonline.com/NG/index.php/analysis/commen tary/31981-on-lekki-toll-road-concession-project (accessed on 29/6/2012).

[12] Nnanna, O. J., Odoko F. O., Alade S. O.(2017); Highway Maintenance in Nigeria, Lessons from other countries, Research Department Occasional Paper Series, Central Bank Of Nigeria.

[13] Osuolale, O. M., Oseni, A. A. and Sanni, I. A (2017). Investigation of Highway Pavement Failure along Ibadan Iseyin Road, Oyo State, Nigeria. International.

[14] Okigbo, N (2017), Road maintenance in Nigeria, the way forward. International journal of research in engineering science. Pan African journal series Accra Ghana.

[15] Salem, T. (2018) 'Federal Roads Begging for Urgent Attention' Leadership Newspaper December 26, http://leadership.ng/news/486582/federal-roads-beggingurgent-attention (accessed on 15/02/19).

[16] The Guardian (2018) 'State of Nigeria's Roads' The Guardian November 8, http://guardian.ng/opinion/state-ofnigeriasroads/ (accessed on 15/12/18).

[17] Thisday Live (2017) 'The Rush Hour? Hour Gridlock at Lekki Toll Plaza'. Thisday Live, April 15, http://www.thisdaylive.com/articles/the-rush-hour-gridlock-atlekki-toll-plaza/113749/ (accessed on 29/6/2017).

[18] Thisday Live (2017) 'The Inevitability of PPP'. Thisdaylive, May 17, https://www.thisdaylive.com/index.php/2017/05/17/theinevitability-of-ppp/ (accessed on 18/06/2017). 